\title{
Setting standards for long term care of the elderly in hospital
}

\section{Ian Philp, Sandra Mawhinney, William J Mutch}

Ninewells Hospital and Medical School, Dundee Ian Philp, MRCP, senior lecturer in geriatric medicine Sandra Mawhinney, medical student

William J Mutch, FRCPED, consultant geriatrician

Correspondence to: Dr I Philp, Level E, Centre Block, Southampton General Hospital, Southampton SO9 $4 \mathrm{XY}$.

BMF 1991:302:1056
In a recent study we found considerable variation in the regime and environment in long term care wards administered by a geriatric service. ${ }^{\prime}$ We report here the process by which we set standards for the regime and environment based on the views of patients and staff in these wards.

\section{Subjects, methods, and results}

We sought the views of the patients and nursing staff in 12 long term care wards in geriatric hospitals. Only 28 of the 188 patients had a score on mental testing greater than or equal to $7 / 10$ and were eligible for inclusion. ${ }^{2}$ We interviewed the two most senior trained nursing staff present when we visited each ward. On two wards only one trained nurse was present during the visit, and we therefore interviewed 22 nursing staff. Interviews were conducted with a schedule of questions about the regime and environment that contained 59 statements derived from questionnaires used to evaluate institutional care.' Subjects were asked to indicate their views by answering the question "Do you think it is appropriate that...?" followed by each statement. Responses were coded as "yes," "no," or "don't know." "Don't know" was classified with "no" as the emphasis of the study was to identify positive preferences.

A greater proportion of nursing staff than patients were in favour of most aspects of the regime and environment, and this was significant for 19 of the 59 statements $\left(p<0.05, \chi^{2}\right.$ test $)$. A majority of both the staff and the patients were in favour of 26 of the statements, which were therefore taken as standards. None of these standards was met by all the wards, but most were met by at least one ward (table).

\section{Comment}

We derived a manageable number of standards for the wards that most of the staff and patients agreed with. The patients had lower expectations than the staff; when this is so a strong case can be made for meeting the patients' preferences. Although we could not obtain the views of most of the patients in the wards, mainly because of cognitive impairment, we believe that most of the standards would improve the patients' quality of life - not by imposing practice on them but by increasing their opportunities.

We did not seek the views of higher management staff, who would be accountable for changes in practice. As most of the staff were in favour of the standards, however, the implementation of changes would be facilitated. Furthermore, as most of the standards were met in some wards we believe that they could be met given the commitment to change.

Measuring the quality of long term care for the elderly is difficult. ${ }^{3}$ Measures such as the quality
Standards for regime and environment in long term geriatric wards, as agreed by most patients and staff interviewed

\begin{tabular}{|c|c|c|c|}
\hline & $\begin{array}{l}\text { Ward } \\
\text { practice } \\
(\mathrm{n}=12)\end{array}$ & $\begin{array}{c}\text { Patients } \\
\text { in favour } \\
(\mathbf{n}=28)\end{array}$ & $\begin{array}{c}\text { Staff } \\
\text { in favour } \\
(\mathbf{n}=22)\end{array}$ \\
\hline \multicolumn{4}{|l|}{ Choice } \\
\hline $\begin{array}{l}\text { There is a telephone available for patients' } \\
\text { use }\end{array}$ & 5 & 28 & 21 \\
\hline $\begin{array}{l}\text { Patients use their bed area whenever they } \\
\text { want }\end{array}$ & 11 & 26 & 22 \\
\hline $\begin{array}{l}\text { If assisted, patients can come and go outside } \\
\text { the ward }\end{array}$ & 7 & 24 & 21 \\
\hline \multicolumn{4}{|c|}{ Patient oriented policies } \\
\hline There are separate toilets for men and women & 1 & 27 & 12 \\
\hline Patients are taught new skills & 5 & 23 & 21 \\
\hline Patients go to bed when they wish & 9 & 22 & 22 \\
\hline There is a noticeboard in the ward & 7 & 19 & 22 \\
\hline There are both smoking and smoke free rooms & 1 & 16 & 22 \\
\hline $\begin{array}{l}\text { There are facilities in the patients' bed area } \\
\text { to lock away possessions }\end{array}$ & 1 & 16 & 11 \\
\hline The ward has a patients' committee & 0 & 16 & 12 \\
\hline \multicolumn{4}{|l|}{ Privacy } \\
\hline Patients have privacy when they wish & 10 & 24 & 12 \\
\hline $\begin{array}{l}\text { There is somewhere patients can make } \\
\text { telephone calls in private }\end{array}$ & 2 & 24 & 20 \\
\hline Patients have privacy for entertaining visitors & 9 & 20 & 22 \\
\hline \multicolumn{4}{|c|}{ Architectural choice } \\
\hline 'There is a patients' shop & 7 & 20 & 20 \\
\hline There are shower $(\mathrm{s})$ in the bathroom $(\mathrm{s})$ & 3 & 17 & 17 \\
\hline There is a chiropody/hairdressing room & 1 & 16 & 19 \\
\hline There is a lounge with no television & 0 & 14 & 20 \\
\hline \multicolumn{4}{|l|}{ Physical amenities } \\
\hline $\begin{array}{l}\text { Bedside lights are provided for and can be } \\
\text { used by all patients }\end{array}$ & 3 & 22 & 21 \\
\hline $\begin{array}{l}\text { All bed areas have electrical socket outlets } \\
\text { that patients can use }\end{array}$ & 10 & 19 & 16 \\
\hline \multicolumn{4}{|c|}{ Sociorecreational aids } \\
\hline There is a garden for patients to sit in & 11 & 27 & 22 \\
\hline $\begin{array}{l}\text { It is easy for mobile patients to get into the } \\
\text { garden unaided }\end{array}$ & 6 & 27 & 20 \\
\hline There is a view of the street/garden/sea from & & & \\
\hline lounges & 11 & 25 & 22 \\
\hline There is a visitors' room & 1 & 24 & 21 \\
\hline \multicolumn{4}{|l|}{ Engagement } \\
\hline $\begin{array}{l}\text { Patients are encouraged to maintain their self } \\
\text { care skills }\end{array}$ & 4 & 28 & 22 \\
\hline Staff encourage patients to help themselves & 11 & 28 & 22 \\
\hline $\begin{array}{l}\text { Staff are encouraged to sit and talk with } \\
\text { patients as part of their job }\end{array}$ & 11 & 20 & 21 \\
\hline
\end{tabular}

adjusted life year are insufficiently sensitive. ${ }^{+}$On the other hand, little things mean a lot in institutional care so that simple changes such as providing a telephone for patients' private use could make a great difference for some patients. Much of geriatric practice has to do with generating optimism in the face of negative expectations about what can be achieved. It is especially difficult to create a challenge in long term care.

We have discussed our results with management and staff, and changes in ward practice are planned. We propose to evaluate the effects of the interventions.

1 Philp I, Mutch WJ, Ballinger B, Boyd I. A comparison of care in private nursing homes, geriatric and psychogeriatric hospitals. International fournal of Geriutric Ps, geriatric and $p$,

2 Wilson LA Brass $W$ Brief assessment of the mental state in geriatric domiciliary practice. The usefulness of mental status questionnaire. Age Ageing 1973:2:92-101.

3 Kane RA, Kane RL. Long term care. Principles, programs and policies. New York: Springer, 1987

4 Donaldson C, Atkinson A, Bond J. QALYS and long term care for elderly people in the UK: scale for assessment of quality of life. Age Ageing 1988:17:379-87.

5 Denham M. A caring home. Care of the Elderly 1989;1:855-6.

(Accepted 28 fanuary 1991)

\section{ONE HUNDRED YEARS AGO}

At the conclusion of the Queen's visit to Grasse, the correspondent of the Times was requested to give an authoritative contradiction to certain statements which had been published (in a medical contemporary) as to the health of Grasse, and as to the sanitary state of the hotel. Careful inquiries were made by experts before the Queen's visit was determined on. The Queen has benefited considerably in health from her stay in Grasse, and whatever disappointment may have been caused by the absence of the genial weather generally experienced there at and after Easter, Her Majesty may be congratulated on having escaped one of the most inclement seasons of biting east wind which the present generation has had to endure-and it has endured much. (British Medical Fournal 1891;i:974) 